\title{
Diet and feeding of Euphausia hanseni and Nematoscelis megalops (Euphausiacea) in the northern Benguela Current: ecological significance of vertical space partitioning
}

\author{
Manuel Barange ${ }^{1, *}$, Mark J. Gibbons ${ }^{2,3}$, Marta Carola ${ }^{4}$ \\ ${ }^{1}$ Instituto de Ciencias del Mar, Paseo Nacional s/n, E-08039 Barcelona, Spain \\ ${ }^{2}$ Marine Biology Research Institute, Department of Zoology, University of Cape Town, Rondebosch 7700, South Africa \\ ${ }^{3}$ Sea Fisheries Research Institute, Private Bag X2, Rogge Bay 8012, South Africa \\ 4 Departamento de Ecologia, Facultad de Biologia, Universidad de Barcelona, Diagonal 645, E-08028 Barcelona, Spain
}

\begin{abstract}
Patterns of diel migration and feeding of Euphausia hanseni and Nematoscelis megalops were investigated in waters of the northern Benguela (Namibia) upwelling system. N. megalops migrated to just below the thermocline at night and fed maximally in the early evening. E. hanseni migrated to above the thermocline at night and fed progressively throughout the night. Although both species were omnivorous and consumed similar size ranges of copepod prey, differential prey sizefrequency with depth resulted in E. hanseni consuming mostly small-sized copepods and $N$. megalops preferring medium size classes. At depths of overlap the 2 species appeared to partition copepod food resources on the basis of size. Vertical spatial partitioning is examined in light of temporal and dietary separation, and overlapping horizontal distribution patterns of the species in the northern Benguela upwelling system. It is concluded that vertical space partitioning is a reflection of the structure of shelf break zooplankton communities, which is a strategy of sharing highly productive areas and avoiding competition.
\end{abstract}

\section{INTRODUCTION}

The continental margins of the oceans are usually characterized by intense spatial variability of the plankton community (Mackas et al. 1985) and dense concentrations of euphausiids are frequently observed at or just beyond the shelf break (Pearcy 1976, Thiriot 1978, Simard et al, 1986). Although in coastal upwelling regions euphausiid biomasses are higher in inshore areas (Smiles \& Pearcy 1971, Pillar \& Stuart 1988, Barange \& Stuart 1991), an increase in the biomass and diversity of the euphausiid community is usually observed near the shelf break (Pillar \& Stuart 1988, Barange \& Stuart 1991). These mesoscale aggregations of euphausiids, that permit them to remain in areas of elevated production, are partially a result of the cou-

\footnotetext{
- Present address: Sea Fisheries Research Institute, Private Bag X2, Rogge Bay 8012, South Africa
}

pling of cross-shelf circulation with euphausiid diel migratory behaviour (Simard et al. 1986, Pillar et al. 1989, Simard \& Mackas 1989).

Diel vertical migration was shown to result in the occupation of different vertical strata by different euphausiid species in the northern Benguela upwelling system (Barange 1990), and has been observed for a number of other zooplankters elsewhere (Zalkina 1970 , Roe 1974, McGowan \& Walker 1979, Simard et al. 1986, Ambler \& Miller 1987, Fenchel et al. 1990, Revelante \& Gilmartin 1990). The significance of vertical space partitioning is that it is expected that zooplankton species that occupy different depth strata will experience reduced competition (DeMott 1989). Although there is circumstantial and experimental evidence that competition could cause vertical segregation (DeMott 1989), direct evidence of competitive interactions between marine planktonic organisms is rare, even though resources must become limited at times, especially in upwelling regions (e.g. Attwood \& Peterson 1989). It 
has been argued that zooplankton can avoid competition by performing vertical migration and vertically partitioning the space (Lane et al. 1978, Ambler \& Miller 1987), but there is some disagreement about what extent of diet or space partitioning is sufficient to infer that competition is a dominant regulatory force in zooplankton communities (Haury \& Wiebe 1982).

Most euphausiids are opportunistic omnivores (Ohman 1984, Simard et al. 1986, Price et al. 1988, Stuart \& Pillar 1990), and switch dietary emphasis from herbivory to carnivory according to ambient conditions (Gibbons et al. 1991). Thus, analysis of feeding and selectivity of vertically segregated species may provide some insight into the extent of partitioning of food resources and the ecological benefits of vertical space partitioning (Angel \& Fasham 1974, Roger 1975, Mullin \& Evans 1976).

In the present paper the feeding of the 2 most numerically abundant euphausiids collected by Barange (1990), Euphausia hanseni and Nematoscelis megalops, is studied during a $48 \mathrm{~h}$ cycle in the northern Benguela upwelling system. Both species are of approximately the same size, but $E$. hanseni occurs maximally in and above the thermocline at night, while N. megalops is located below (Barange 1990). The objective of this study was to assess the extent of dietary overlap and the criteria for food choice, with a view to examining resource partitioning between the dominant species. Investigations on the horizontal and vertical distribution of both species in the northern Benguela upwelling system will provide some insight into the advantages of vertical segregation and implications for the structure of shelf break zooplankton communities.

\section{MATERIAL AND METHODS}

Sample collection. Samples were collected over a $48 \mathrm{~h}$ period in April 1986 off the coast of Namibia $\left(18^{\circ} \mathrm{S}, 10^{\circ} 30^{\prime} \mathrm{E}_{i}\right.$ Fig. 1), as part of the second SNEC (Spanish-Namibian Environmental Cruise). The study area was characterized by abated upwelling conditions, although upwelling was noticeable in the southern part of the sampling grid (Maso 1987; Fig. 1). A strong intrusion of warm, more saline, Angola water from the north-northwest was also observed, which advanced at an average rate of 5 miles per day (Boyd et al. 1987).

CTD/Niskin rosettes were cast at the fixed station every $4 \mathrm{~h}$ to determine temperature and salinity profiles, and to collect water for nutrients and chlorophyll analysis. Zooplankton samples were taken by means of a multiple opening-closing Rectangular Midwater Trawl (RMT $1 \times 6$ ), fitted with $200 \mu \mathrm{m}$ mesh and fished

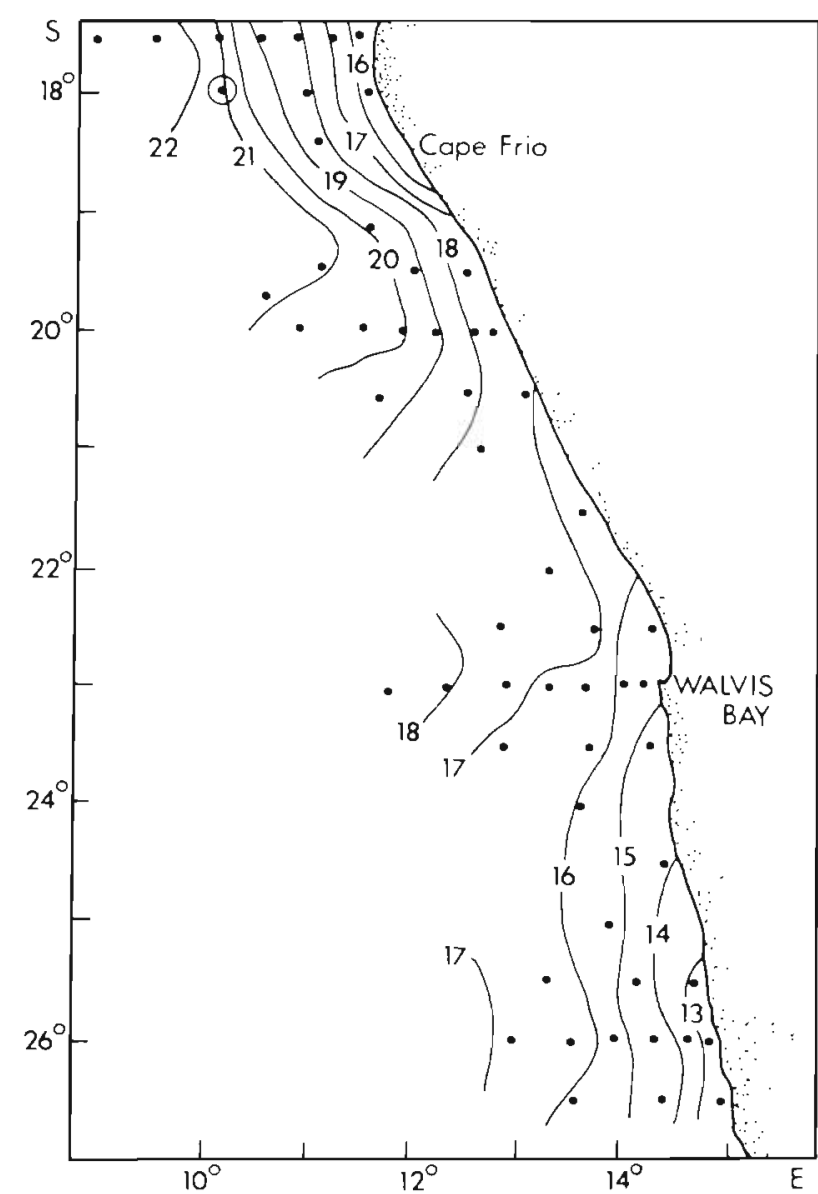

Fig. 1 The northern Benguela region showing the position of the sampling station (ringed dot) and the SNEC II (SpanishNamibian Environment Cruise II) grid. The horizontal distribution of surface temperature is also shown

at 5 different layers in the upper $200 \mathrm{~m}$ of the water column: $200-100,100-60,60-40,40-20$ and 20 to $0 \mathrm{~m}$. Samples were fixed in $4 \%$ buffered seawater formalin for later processing. More detailed descriptions of the methodology can be found in Barange (1990).

Sample processing. Adults of Euphausia hanseni and Nematoscelis megalops were sexed and counted from each collection. At selected times and depths, chosen according to the densities recorded, the stomach contents of measured specimens were then examined from samples spanning a $24 \mathrm{~h}$ period (Table 1). Visual estimates of stomach fullness were made and indices scored on a 0 (completely empty) to 10 (completely full) basis (cf. Ponomareva 1971).

After dissection of the stomachs, the contents were examined at $\times 160$ magnification for copepod mandibles. The width of each blade was measured, and the number of copepods consumed estimated from the total number of matched pairs and unmatched mandibles per stomach. Copepod prosome lengths were estimated from mandible widths (Stuart \& Pillar 1990). 
Table 1. Times and depths of RMT samples from which euphausiids were taken for stomach analysis. The number of individuals examined in each instance is also indicated (n)

\begin{tabular}{|cllcccc|}
\hline \multicolumn{3}{c}{ Euphausia hanseni } & \multicolumn{3}{c|}{ Nematoscelis megalops } \\
Time (h) Depth (m) & $\mathrm{n}$ & Time (h) Depth (m) & $\mathrm{n}$ \\
\hline $20: 00$ & $60-100$ & 20 & $4: 40$ & $40-60$ & 20 \\
$20: 00$ & $40-60$ & 20 & $4: 40$ & $20-40$ & 20 \\
$22: 30$ & $60-100$ & 20 & $4: 40$ & $0-20$ & 20 \\
$22: 30$ & $40-60$ & 20 & $8: 40$ & $100-200$ & 20 \\
$4: 40$ & $60-100$ & 20 & $10: 30$ & $100-200$ & 10 \\
$4: 40$ & $40-60$ & 20 & $12: 30$ & $100-200$ & 20 \\
$20: 20$ & $60-100$ & 20 & $16: 00$ & $100-200$ & 20 \\
$20: 20$ & $40-60$ & 20 & $20: 20$ & $20-40$ & 20 \\
$20: 20$ & $20-40$ & 20 & $20: 20$ & $0-20$ & 20 \\
$22: 30$ & $60-100$ & 7 & $22: 30$ & $40-60$ & 20 \\
$22: 30$ & $40-60$ & 20 & $22: 30$ & $0-20$ & 20 \\
$22: 30$ & $20-40$ & 20 & $2: 20$ & $20-40$ & 40 \\
$2: 20$ & $60-100$ & 17 & $2: 20$ & $0-20$ & 30 \\
$2: 20$ & $40-60$ & 23 & $6: 20$ & $20-40$ & 20 \\
& & & $6: 20$ & $0-20$ & 20 \\
\hline
\end{tabular}

Data analysis. Single Factor Kruskall Wallis analyses were used to test for significance between data. Unlabelled levels of significance quoted subsequently refer to these analyses, which together with means and $95 \%$ confidence limits were calculated using Statgraphics software.

Samples of euphausiids at night were analysed by Chi-square (at the $95 \%$ level of significance) to determine whether or not copepod prey were selected on the basis of size. Mandibles from stomach samples were sorted by size class to provide observed frequencies. Expected frequencies were calculated from water column proportions, which in turn were estimated from the sum of water column counts at the depth of capture and prior foraging depths to an equivalent of the gut passage time. A gut passage time of $70 \mathrm{~min}$, estimated for Euphausia lucens by Stuart \& Pillar (1990), was used to estimate prior foraging depths (Gibbons et al. 1991).

\section{RESULTS}

A detailed description of the hydrographic results are provided by Maso (1987). Summarised profiles of chlorophyll $a$ and sigma-t are presented in Fig. 2. A weak thermocline $\left(4^{\circ} \mathrm{C}\right)$ was present throughout the $48 \mathrm{~h}$ period at 20 to $40 \mathrm{~m}$ and chlorophyll maxima were consistently recorded above this.

Copepod abundances were greatest in the surface waters and declined markedly with depth (Fig. 2). The copepod community was dominated by small individuals (0.2 to $0.3 \mathrm{~mm}$ prosome length), particularly Oithona plumifera, although 'medium' $(0.7$ to $1.0 \mathrm{~mm})$ sized copepods were common below $20 \mathrm{~m}$ depth (Fig. 3).

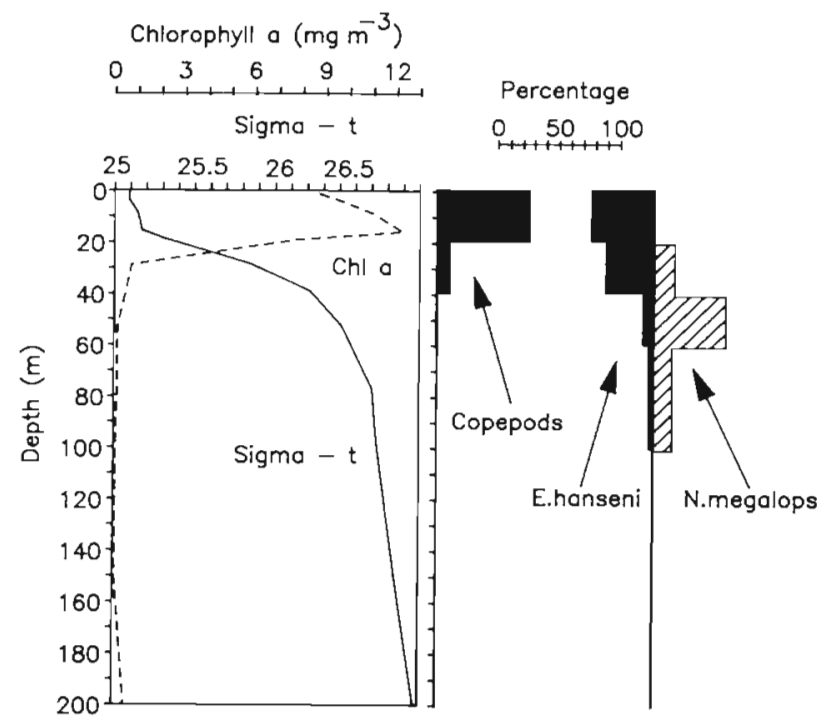

Fig. 2. Chlorophyll $a$ and sigma-t profiles of the study site at the beginning of the sampling period. The average distribution of total copepods, and Euphausia hanseni and Nematoscelis megalops adults, at night (as percent) in the water column is also shown (from Barange 1990)

Changes in the vertical distribution of some copepods were evident at night but, since $O$. plumifera main. tained a near static position, the size composition of communities changed little (M. Carola unpubl.).

Copepods, dinoflagellates and tintinnids were the most common food items in the stomachs of Euphausia hanseni and Nematoscelis megalops, while foraminifera and chaetognaths were rare. Diatoms were



Fig. 3. Copepod size frequency (prosome length) in different layers of the water column during nighttime 

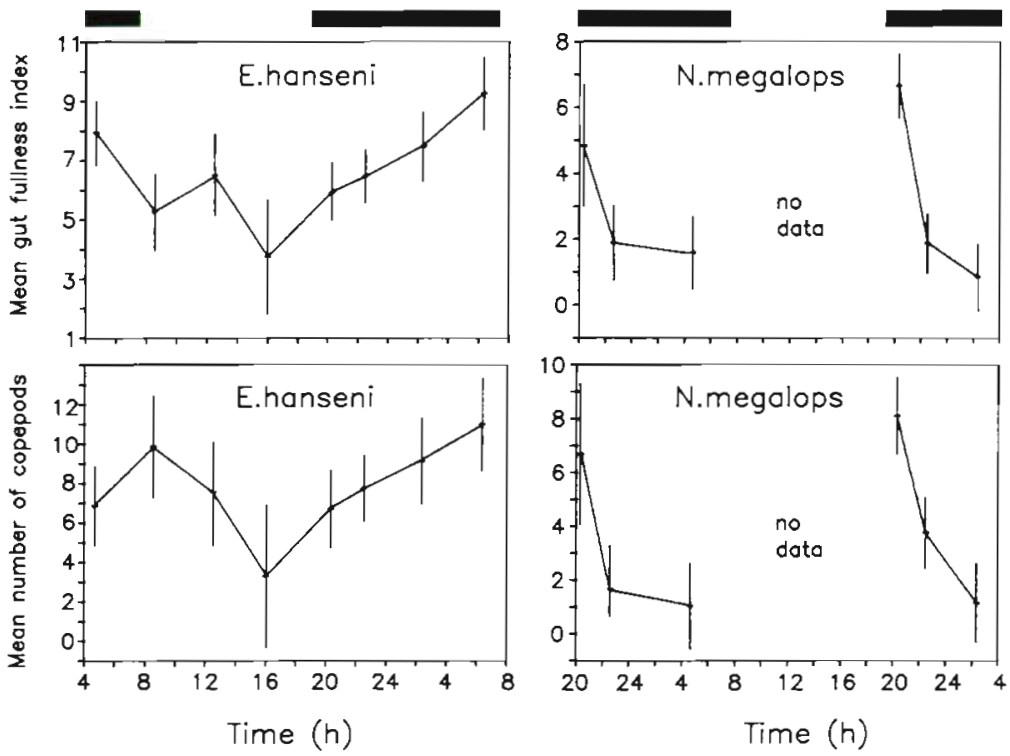

Fig. 4. Euphausia hanseni and Nematoscelis megalops. Diel variations in mean gut fullness and number of copepods per euphausiid. Vertical lines indicate standard deviation recorded in $E$. hanseni but not in $N$. megalops, and stomachs of the latter contained oil up to $80 \%$ by volume. The tendency for gut fullness indices and number of copepods consumed to increase with species length (Table 2) was significant only for $E$. hanseni $(p<0.05)$. Males ate as much as females of the same species $(p>0.05)$.

The mean gut fullness and number of copepods consumed by Euphausia hanseni were significantly $(p<0.05)$ higher at night than during the day (Fig. 4). These were lowest at around 16:00 h and increased consistently throughout the night to peak at between 06:00 $\mathrm{h}$ and 08:00 h. By contrast, the mean gut fullness

Table 2. Euphausia hanseni and Nematoscelis megalops. Relationship between size, mean gut fullness, mean number of copepods per stomach and mean copepod length. Data are pooled from all sampling depths and times. Numbers in parentheses denote standard deviation

\begin{tabular}{|c|c|c|c|c|c|c|}
\hline \multirow{2}{*}{$\begin{array}{l}\text { Euphausiid } \\
\text { size class } \\
\text { (mm) }\end{array}$} & \multicolumn{2}{|c|}{$\begin{array}{l}\text { Gut fullness } \\
\text { index }\end{array}$} & \multicolumn{2}{|c|}{$\begin{array}{l}\text { No. of } \\
\text { copepods }\end{array}$} & \multicolumn{2}{|c|}{$\begin{array}{c}\text { Copepod } \\
\text { length }(\mathrm{mm})\end{array}$} \\
\hline & $\bar{x}$ & $\mathrm{SD}$ & $\bar{x}$ & $\mathrm{SD}$ & $\bar{x}$ & $\mathrm{SD}$ \\
\hline \multicolumn{7}{|c|}{ Euphausia hansenj } \\
\hline $18-20$ & 5.5 & $(2.4)$ & 5.5 & $(4.5)$ & 0.45 & $(0.08)$ \\
\hline $20-22$ & 5.8 & $(0.9)$ & 5.4 & $(1.6)$ & 0.40 & $(0.03)$ \\
\hline $22-24$ & 7.2 & $(0.6)$ & 5.6 & $(1.2)$ & 0.46 & $(0.02)$ \\
\hline $24-26$ & 7.1 & $(0.7)$ & 9.1 & $(1.3)$ & 0.47 & $(0.02)$ \\
\hline $26-28$ & 8.2 & $(0.7)$ & 9.5 & (1.3) & 0.48 & $(0.02)$ \\
\hline $28-30$ & 8.5 & $(1.2)$ & 14.4 & $(2.2)$ & 0.51 & $(0.03)$ \\
\hline $30-32$ & 9.3 & $(2.2)$ & 14.3 & $(4.2)$ & 0.57 & $(0.05)$ \\
\hline \multicolumn{7}{|c|}{ Nematoscelis megalops } \\
\hline $14-16$ & 3.8 & $(3.2)$ & 4.6 & $(4.2)$ & 0.46 & $(0.24)$ \\
\hline $16-18$ & 2.9 & $(1.0)$ & 4.7 & (1.3) & 0.52 & $(0.04)$ \\
\hline $18-20$ & 3.7 & $(0.8)$ & 5.2 & (1.1) & 0.57 & $(0.03)$ \\
\hline $20-22$ & 4.1 & $(1.1)$ & 4.4 & $(1.5)$ & 0.59 & $(0.05)$ \\
\hline $22-24$ & 6.7 & $(2.7)$ & 8.0 & $(3.6)$ & 0.63 & $(0.07)$ \\
\hline
\end{tabular}

and number of copepods consumed by Nematoscelis megalops were significantly $(p<0.05)$ higher in the early evening than they were later on (Fig. 4), peaking at around 20:00 h and declining thereafter. Diurnal consumption is unknown, as insufficient specimens were caught with which to make viable comparisons.
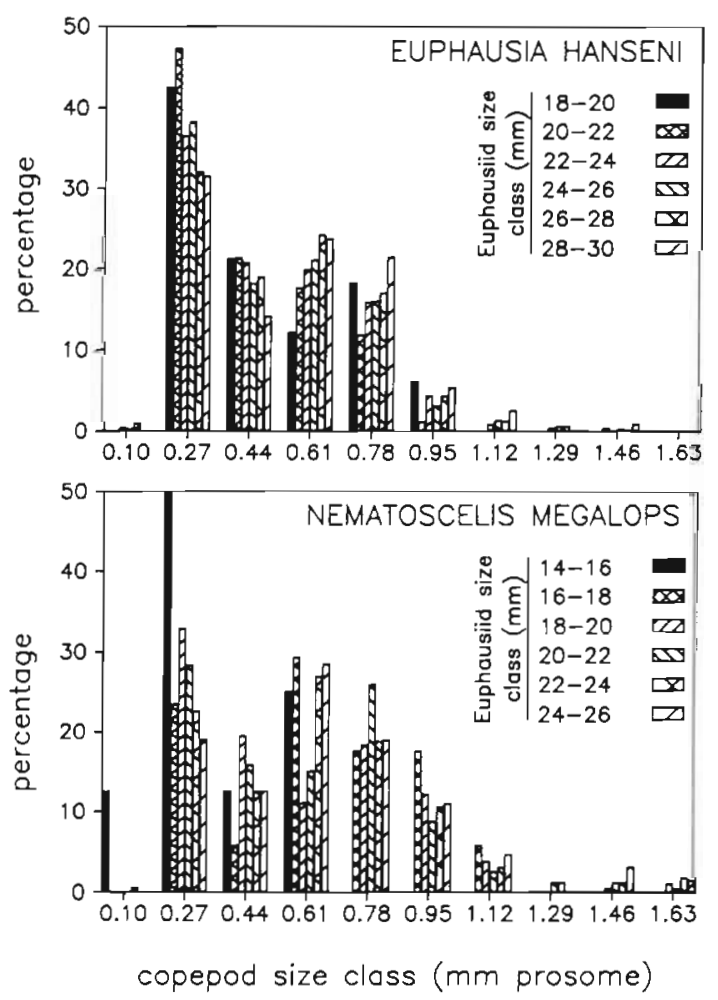

Fig. 5. Euphausia hanseni and Nematoscelis megalops. Histograms illustrating changes in the copepod size (prosome length) composition of euphausiid diets with euphausiid size 
Both species ate a similar size range of copepods and, while small copepods made up the bulk of these, the prey-size spectra included greater proportions of large copepods with increasing euphausiid length (Fig. 5). Nematoscelis megalops consumed slightly (but significantly) larger copepods than comparable sized Euphausia hanseni.

Table 3 suggests that both species of euphausiids consumed copepods of different sizes at ambient proportions, or according to inconsistent patterns of selec- tion. However, a more thorough examination of this, as well as of patterns of selection at overlapping times and depths (Fig. 6), reveals that patterns of prey choice were different for the 2 species of euphausiids at most depths. Although stomach contents largely reflect ambient proportions, Euphausia hanseni consistently selected small prosome length copepods $(0.2$ to $0.3 \mathrm{~mm}$ ). Patterns of selection on larger copepods were inconsistent. Nematoscelis megalops consistently consumed copepods between 0.6 and $1.0 \mathrm{~mm}$ prosome
Fig. 6. Size distribution of copepods (prosome length) in the water column (๑) and diets of Euphausia hanseni $(\bullet . . . \bullet)$ and Nematoscelis megalops (-.--) at different depths and at times that correspond to the peak feeding of $N$. megalops

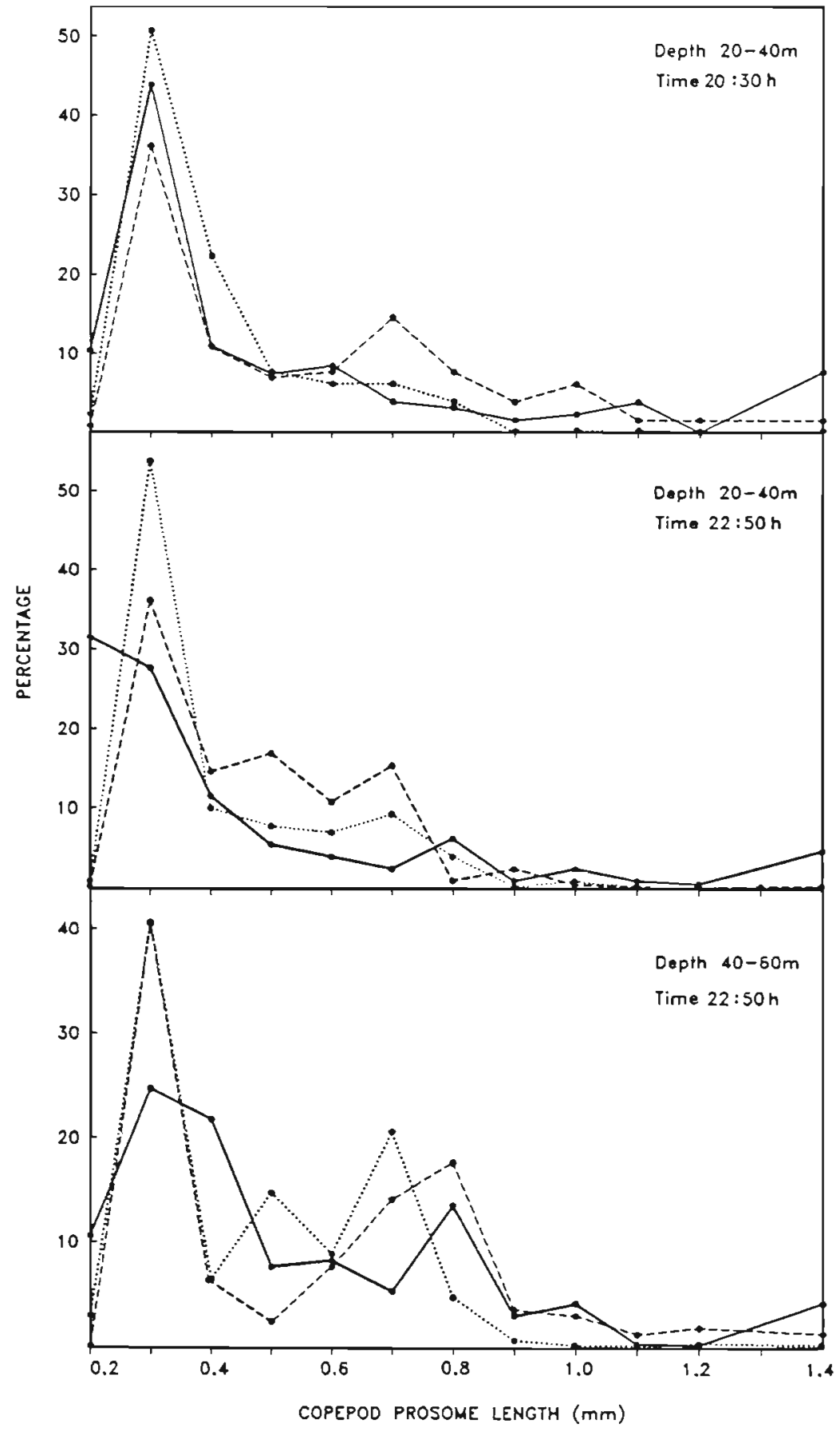




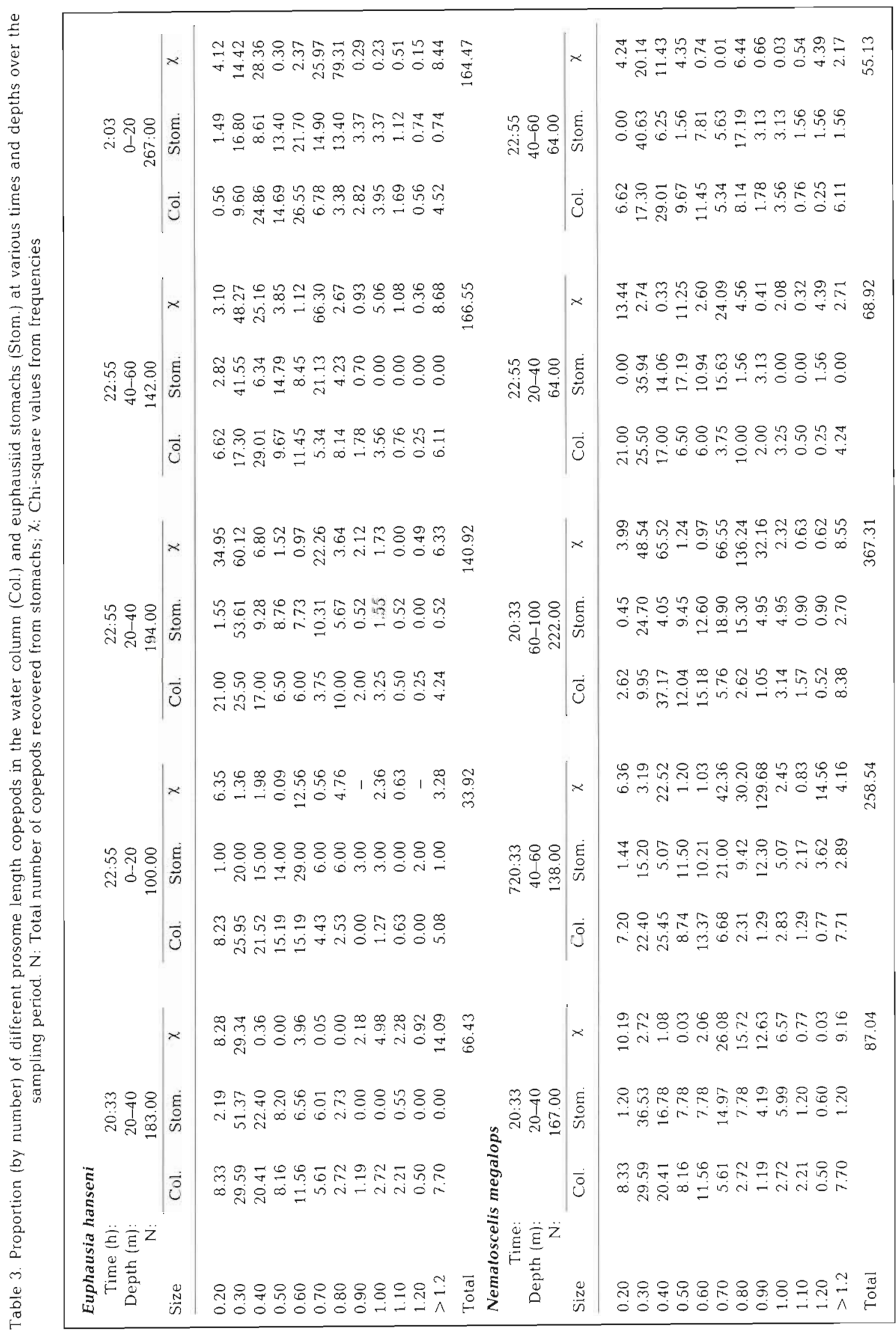


length at greater proportions than ambient proportions and ignored small prosome length copepods except at greater depths (40 to $60 \mathrm{~m}$; Table 3, Fig. 6). The mean length of copepods consumed by $N$. megalops $(0.49 \mathrm{~mm})$ was significantly $(\mathrm{p}<0.05)$ greater than those consumed by E. hanseni $(0.39 \mathrm{~mm})$ at overlap depths at the beginning of the night period, suggesting that at overlapping times and depths food resources were partitioned on the basis of size.

\section{DISCUSSION}

Roger (1975) concluded that the less extensive is the diel migration of euphausiid species, the more pronounced is the feeding rhythm. Although diel vertical migration was observed for both species (Barange 1990), Nematoscelis megalops migratory patterns are still uncertain (Wiebe et al. 1982, Roe et al. 1984, Barange 1990), but in any case less marked than those of Euphausia hanseni. The results obtained suggest that the 2 species are vertically segregated, and their differential migratory habits are reflected in their cyclic feeding behaviour and food preference. Barange (1990) showed that vertical segregation was extended to the whole euphausiid community, suggesting that the 2 species considered are examples of sub-communities of the whole community (sensu Angel \& Fasham 1974). With diffuse competition (Lane et al. 1978) by other species (Barange 1990) not to be dismissed, the results presented are evidence for a strong structure of the shelf break zooplankton community during the study.

The diel feeding rhythms of Euphausia hanseni and Nematoscelis megalops are markedly different and support the contention that feeding rhythms are genusspecific (Roger 1975). Although scarcity of data does not permit strong conclusions in this respect, it seems that both species increase their feeding activity when the potential prey is maximum in their respective habitats. Thus, E. hanseni comes in contact with highest food concentrations near the surface at night, while $N$. megalops migrates to the thermocline layer and feeds when the bulk of the migratory mesozooplankton community is expected to cross this layer. This observation suggests that feeding is triggered by food availability and that it is a reflection of the concentrations of food in the environment (cf. Simard et al. 1986). Furthermore, the results suggest that the differential feeding time and prey selection observed could be a result of the strong phenotypical plasticity of the species involved.

Patterns of prey choice and hence bases for copepod selection by the 2 species of euphausiid are different. The high incidence of small copepods in the stomachs of Euphausia hanseni suggests that prey were selected passively on an incidental encounter basis. Small copepods are not only slower than large (Fleminger \& Clutter 1965, Lampitt 1978, Landry 1978) but also are more susceptible to predation via negative pressure (Singarajah 1969, 1975), so their predominance in the diet of a non-hunting (Mauchline 1980) preferential herbivore is no surprise. On the other hand, species that possess elongated thoracic appendages, such as Nematoscelis megalops, have a more carnivorous diet than species that lack them (Roger 1973). Such cormopods are thought to enhance the ability to catch and sort prey, although hard experimental evidence is lacking (Berkes 1975).

Euphausia hanseni and Nematoscelis megalops are the most abundant euphausiid species at and just beyond the shelf break in the northern Benguela ( $M$. Barange unpubl.). This area is characterized by perennial upwelling (Stander 1964, Boyd \& Agenbag 1985, Shannon 1985) and a weakly stratified water column (Du Plessis 1967. Shannon 1985), which at the study site was strengthened by the seasonal intrusion of warm surface water (Boyd et al. 1987). Although euphausiids are generally able to cross strong thermal gradients (e.g. Williams \& Frangopoulu 1985), there is growing evidence that different species select their vertical position according to the structure of the water column (Roger 1971, Barange 1990). In particular, Wiebe \& Boyd (1978) noted that the position of $N$. megalops in a water column of cold water rings changed as the ring matured and warmed up, and that the euphausiids showed a preference for specific temperature regimes. However, when the vertical distributions of $N$. megalops and $E$. hanseni from different surveys and areas inside the northern Benguela (Olivar \& Barange 1990, Barange \& Stuart 1991) are plotted (Fig. 7), the pattern of vertical segregation is maintained, suggesting that it cannot be explained by water column structure alone. The figure also represents their densities on those occasions when both species were present in the water column. In only $10 \%$ of the collections where $E$. hanseni was collected did $N$. megalops not co-occur, suggesting that their horizontal distributions largely overlap. Since their abundances follow a linear relationship (Fig. 7) it is strongly suggested that biological interactions and plankton mobility are responsible for the patterns observed (Haury \& Wiebe 1982). Segregation in the vertical dimension provides a means of niche partitioning for potentially competitive species, a fact that has been observed for sibling species of comparable size (Baker 1970, Roe 1974, Roger 1975, Mullin \& Evans 1976, Ambler \& Miller 1987). By selectively preying upon different components of the copepod population the diversity of the community is compounded further, and the impact of predation homogenized over a large part of the water column. Selection of areas of elevated production (Price 1989), such as the shelf edge (Simard \& Mackas 1989), by different species is likely to result in 


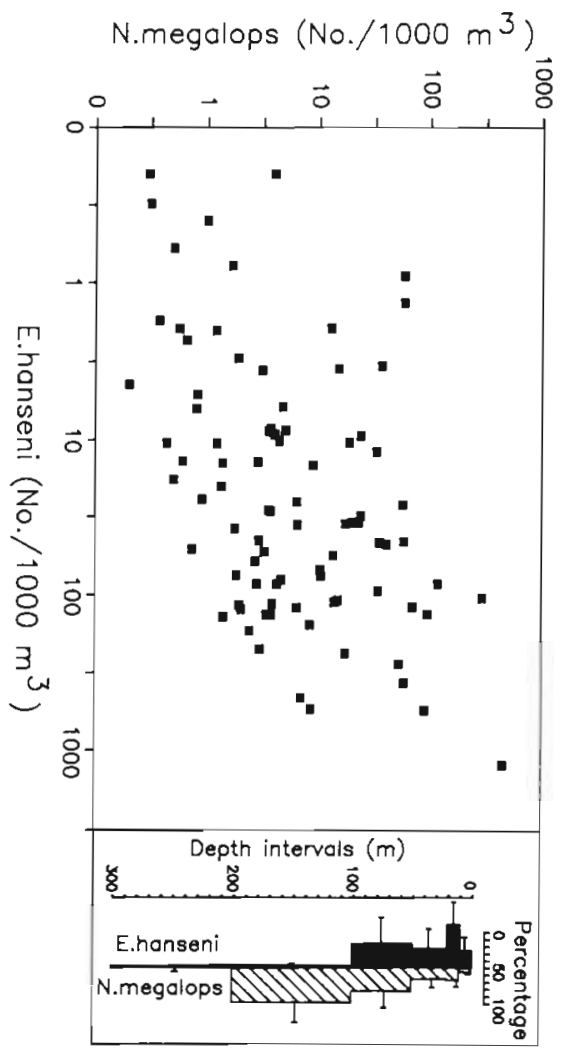

Fig. 7. Scatterplot showing the relationship between horizontal abundances of Euphausia hanseni and Nematoscelis megalops (at overlapping stations) and their average vertical distribution at night, in the northern Benguela Current. The figure was constructed using data collated from 2 SNEC (Olivar \& Barange 1990, Fig. 1) and 5 SWAPELS (South West Africa Pelagic Eggs and Larvae Surveys; Barange \& Stuart 1991) surveys

competitive interactions unless mechanisms like vertical segregation are employed. Thus, the high diversity of assemblages generally encountered at continental margins probably reflects the existence of strong zooplankton structure, derived from both evolutionary changes and phenotypical plasticity, as evidenced by the amount of interdependence among the different species.

Acknowledgements. We thank Drs Stan Pillar and Larry Hutchings for critically reading various drafts of the manuscript. M.B. and M.J.G. acknowledge the Sea Fisheries Research Institute of Cape Town for providing them with working facilities during the development of this work. M.J.G. was funded by a grant for the Benguela Ecology Programme from the South African National Committee for Oceanographic Research (SANCOR):

\section{LITERATURE CITED}

Ambler, J. W., Miller, C. B. (1987). Vertical habitat-partitioning by copepodites and adults of subtropical oceanic copepods. Mar Biol. 94: 561-577

Angel, M. V. Fasham, M. J. R. (1974). SOND cruise 1965 : further factor analyses of the plankton data. J. mar. biol. A.ss. U.K. 54 : 879-894

Attwood, C. G., Peterson, W T (1989). Reduction in fecundity and lipids of the copepod Calanus australis (Brodskii) by strongly pulsed upwelling. J. exp. mar. Biol. Ecol. 129; 121-131

Baker, A. de C. (1970). The vertical distribution of euphausids near Fuerteventura, Canary Islands ('Discovery' Sond Cruise, 1965). J. mar. biol. Ass. U.K. 50: 301-342

Barange, M. (1990). Vertical migration and habitat partitioning of six euphausid species in the northem Benguela upwelling system. J. Plankton Res. 12, 1223-1237

Barange, M., Stuart, V. (1991). Distribution patterns, abundance and population dynamics of the euphausids Euphausia hanseniand Nyctiphanes capensis in the northern Benguela upwelling system. Mar. Biol. 109: 93-101

Berkes, F. (1975). Some aspects of feeding mechanisms of euphausiid crustaceans. Crustaceana 29: 266-270

Boyd, A. J., Agenbag, J. J. (1985). Seasonal trends in the Iongshore distribution of surface temperatures off Southwestern Africa $18-34^{\circ} \mathrm{S}$, and their relation to subsurface conditions and currents in the area $21-24^{\circ} \mathrm{S}$. In: Bas, C. Margalef, R., Rubies, P. (eds.) International Symposium on the Most Important Upwelling Areas off Western Africa (Cape Blanco and Benguela), Vol. 1 Instituto de Investigaciones Pesqueras, Barcelona, p. 119-148

Boyd, A. J., Salat, J., Maso, M. (1987). The seasonal intrusion of relatively saline water on the shelf off northern and central Namibia. In: Payne, A. I. L., Gulland, J. A., Brink, K. H. (eds.) The Benguela and comparable ecosystems. S. Afr. J. mar. Sci. 5: $107-120$

DeMott, W. R. (1989). The role of competition in zooplankton succession. In: Sommer, U. (ed.) Plankton ecology. Succession in plankton communities. Springer-Verlag, Berlin, p. 195-252

Du Plessis, E. (1967). The pilchard of South West Africa (Sardinops ocellata). Seasonal ocurrence of thermoclines off Walvis Bay, South West Africa, 1959-1965. Investl Rep. mar. Res. Lab. S. W. Afr 13, 16 p.

Fenchel, T., Kristensen, L. D., Rasmussen, L. (1990). Water column anoxia: vertical zonation of planktonic protozoa. Mar Ecol. Prog. Ser. 62: 1-10

Fleminger, A., Clutter, R. I. (1965). Avoidance of towed nets by zooplankton. Limnol. Oceanogr. 10: 96-104

Gibbons, M. J., Barange, M., Pillar, S. C. (1991). Diel migration and feeding of Euphausia lucens in the southern Benguela. J. Plankton Res. 13: 473-486

Haury, L. R., Wiebe, P. H. (1982). Fine-scale multispecies aggregations of oceanic plankton. Deep Sea Res. 29: 915-921

Lampitt, R. S. (1978). Carnivorous feeding by a small calanoid copepod. Limnol. Oceanogr. 23: 1228-1231

Landry, M. R. (1978). Predatory feeding behavior of a marine copepod, Labidocera trispinosa. Limnol. Oceanogr. 23 $1103-1113$

Lane, P. A., Makarewicz, J. C., Likens, G. E. (1978). Zooplankton niches and the community structure controversy. Science 200: 458-463

Mackas, D. L., Denman, K. L., Abbott, M. R. (1985). Plankton patchiness: biology in the physical vernacular Bull. mar Sci. 37: 652-674

Maso, M. (1987). Preliminary hydrological results of the 'Spanish Namibian Environmental Cruise' survey, SNEC II Colln Sci. Pap. Int. Commn SE Atl. Fish. 14: 113-128

Mauchline, J. (1980). The biology of mysids and euphausiids. Adv mar. Biol. 18: 1-681

McGowan, J. A., Walker, P. W (1979). Structure in the 
copepod community of the North Pacific central gyre. Ecol. Monogr. 49: 195-226

Mullin, M. M., Evans, P. M. (1976). Distribution, morphometry and seasonal biology of the planktonic copepods Neocalanus robustior and Neocalanus gracilis in the Pacific ocean. Pacif. Sci. 30: 119-130

Ohman, M. D. (1984). Omnivory by Euphausia pacifica: the role of copepod prey. Mar. Ecol. Prog. Ser 19: 125-131

Olivar, M. P., Barange, M. (1990). Zooplankton of the northern Benguela region in a quiescent upwelling period. J. Plankton Res. 12: 1023-1044

Pearcy, W. C. (1976). Seasonal and inshore-offshore variations in the standing stocks of micronekton and macrozooplankton off Oregon. Fish. Bull. U.S. 74: 70-80

Pillar, S. C., Stuart, V. (1988). Population structure, reproductive biology and maintenance of Euphausia lucens in the southern Benguela current. J. Plankton Res. 10: 1083-1098

Pillar, S. C., Armstrong, D. A., Hutchings, L. (1989). Vertical migration, dispersal and transport of Euphausia lucens in the southern Benguela Current. Mar. Ecol. Prog. Ser. 53: $179-190$

Ponomareva, L. A. (1971). Circadian migrations and feeding rhythm of some Indian Ocean euphausiid species. Oceanology 11: 226-231

Price, H. J. (1989). Swimming behavior of krill in response to algal patches: a mesocosm study. Limnol. Oceanogr. 34: 649-659

Price, H. J., Boyd, K. R., Boyd, C. M. (1988). Omnivorous feeding behavior of the Antarctic krill, Euphausia superba. Mar. Biol. 97: 67-77

Revelante, N., Gilmartin, M. (1990). Vertical water column resource partitioning by a ciliated protozoan population under stratified conditions in the northern Adriatic. J. Plankton Res. 12: 89-107

Roe, H. S. J. (1974). Observations on the diurnal vertical migrations of an oceanic animal community. Mar. Biol. 28: $99-113$

Roe, H. S. J., James, P. T., Thurston, M. H. (1984). The diel migrations and distributions within a mesopelagic community in the North East Atlantic. 6. Medusae, ctenophores, amphipods and euphausids. Prog. Oceanogr. 13: $425-460$

Roger, C. (1971). Distribution verticale des euphausiacés (crustacés) dans les courants équatoriaux de l'Ocean Pacifique. Mar. Biol. 10: 134-144

Roger, C. (1973). Recherches sur la situation trophique d'un

This article was submitted to the editor groupe d'organismes pélagiques (Euphausiacea). I. Niveaux trophiques des espéces. Mar Biol. 18: 312-316

Roger, C. (1975). Rythmes nutritionnels et organisation trophique d'une population de crustacés pélagiques (Euphausiacea). Mar. Biol. 32: 365-378

Shannon, L. V (1985). The Benguela ecosystem. 1. Evolution of the Benguela, physical features and processes. Oceanogr mar Biol. Ann. Rev. 23: 105-182

Simard, Y., Ladurantaye, R., Therriault, J. C. (1986). Aggregation of euphausiids along a coastal shelf in an upwelling environment. Mar. Ecol. Prog. Ser 32: 203-215

Simard, Y., Mackas, D. L. (1989). Mesoscale aggregations of euphausiid sound scattering layers on the continental shelf of Vancouver Island. Can. J. Fish. Aquat. Sci. 46: $1238-1249$

Singarajah, K. V. (1969). Escape reactions of zooplankton: the avoidance of a pursuing siphon tube. J. exp. mar. Biol. Ecol. 3: 171-178

Singarajah, K. V. (1975). Escape reactions of zooplankton: effects of light and turbulence. J. mar. biol. Ass. U.K. 55: $627-639$

Smiles, M. C., Pearcy, W. G. (1971). Size structure and growth rate of Euphausia pacifica off the Oregon coast. Fish. Bull. U.S. $69: 79-86$

Stander, G. H. (1964). The Benguela current off South West Africa. Investl Rep. mar. Res. Lab. S.W. Afr. 12: 1-43

Stuart, V., Pillar, S. C. (1990). Diel grazing patterns of all ontogenic stages of Euphausia lucens and in situ predation rates on copepods in the southern Benguela upwelling region. Mar. Ecol. Prog. Ser. 64: 227-241

Thiriot, A. (1978). Zooplankton communities in the West African upwelling area. In: Boje, R., Tomczak, M. (ed.) Upwelling ecosystems. Springer-Verlag, Berlin, p. 32-61

Wiebe, P. H., Boyd, S. H. (1978). Limits of Nematoscelis megalops in the Northwestern Atlantic in relation to Gulf Stream cold core rings. I. Horizontal and vertical distributions. J. mar Res. 36: 119-142

Wiebe, P. H., Boyd, S. H., Dais, B. M., Cox, J. L. (1982). Avoidance of towed nets by the euphausiid Nematoscelis megalops. Fish. Bull. U.S. 80: 75-91

Williams, R., Frangopoulu, N. (1985). Vertical distribution and nocturnal migration of Nyctiphanes couchii (Crustacea: Euphausiacea) in relation to the summer thermocline in the Celtic Sea. Mar. Biol. 89: 257-262

Zalkina, A. V. (1970). Vertical distribution and diurnal migration of some Cyclopoida (Copepoda) in the tropical region of the Pacific ocean. Mar. Biol. 5: 274-282

Manuscript first received: December 11, 1990

Revised version accepted: April 24, 1991 